\title{
Work-Life Balance and Employee Performance: A Literature Review
}

\author{
Miebaka Dagogo Tamunomiebi and Constance Oyibo
}

\begin{abstract}
This paper is a review of literature on work life balance and employee performance in Nigeria as an attempt at knowledge building. This is a secondary research which sought to review literature in assessing work life balance in Nigeria and suggest suitable solutions for overcoming the problem of work life imbalance and its associated negative spill over in order to enhance employee performance for optimum organizational output. We posit that employees who have balanced work and non-work roles are more likely to perform better, thus it is essential for employers to promote policies and structures that enhance work life balance of employees in their organisations. We conclude that there are systemic barriers that hinder the implementation of work life balance policies in Nigeria, such as leadership failure which has birthed political, economic and social challenges that are the primary sources of work life conflict, they include corruption, weak institutions that lack the capacity to monitor and enforce employment standards, high unemployment ratios, poverty, inflation and a plethora of others. We recommend that organisations provide flexible work arrangements to be enforced by government legislations that will statutorily empower employees to request for atypical work patterns, that the awareness of organisations be raised to the advantages of protecting workers' rights to various leave initiatives that will improve employee wellbeing and managerial training to ensure managerial support for the demands of these policies.
\end{abstract}

Index Terms- Employee Performance, Flexi-Time, Work Leave Initiatives, Work Life Balance.

\section{INTRODUCTION}

The employee is a very vital asset in an organisation and the most important in performing the organisational process and achieving organisational goals. However, the challenge of every organisation is how to optimize employee performance. Employee performance is defined as "the level of success of employees in carrying out their duties and responsibilities" (Rachmaliya \& Effendy, 2017:42). Employee performance is key in determining the achievement of organizational goals; therefore organisations look for ways to motivate their employees to give their best performance on the job. Although the topic of employee performance has been comprehensively explored in the western context, there has been very little research on task performance of employees in the Nigerian context. Available management literature shows that research on the prediction of employee task performance focuses more on the direct effects of various types of single variables (Sung $\&$ Choi, 2012). Among the human resources management

Published on April 05, 2020

Miebaka Dagogo Tamunomiebi, Rivers State University, Nigeria

(e-mail: tamunomiebi2002@yahoo.com ).

Constance Oyibo, Rivers State University, Nigeria

(e-mail: constanceoyibo@gmail.com). procedures available, enriching work-life balance has been well-thought-out as one of the major high performance HRM practices that increasingly promotes the enhancement of employee performance (Hyde, Sparrow, Boaden\& Harris, 2013).

Traditionally, human resource practitioners' approach to improving performance was evaluation of previous performance and allocation of reward in exchange for improved performance. However, this does not take into consideration the intrinsic interests of employees who do the work, hence it is no longer sufficient. In recent times, organizational policies are aimed at creating a conducive environment for motivating employees both through internal and external means in order to improve and increase performance. According to Thevanes and Mangaleswaran (2018), organizations are focusing on employing several high performance human relations measures and action plans to boost employee performance and work life balance is an important tool in this regard.

The impact of work-life balance on employee performance and on the general success of any organization cannot be overemphasized. According to Orogbu, Onyeiugbe and Chukwuemeka (2015), the individual is an integral part of the family in particular and the society in general, therefore, work life balance is an important phenomenon and is of great concern to both private and public sector organisations. The ability of an employee to have a satisfactory fit between his job and other roles is a very crucial factor in determining his performance on the job. Work-life balance policies are key factors for the success of an organization that depends on its employees for the achievement of organisational goals. Kossek, Lirio and Valcour (2013:301) define work life balance as "satisfaction and perceptions of success in meeting work and non-work role demands, low levels of conflict among roles and opportunity for inter-role enrichment." The concept in this context is not restricted to prioritizing work and personal life roles of employees but also includes how it affects employees' psychological, economic and mental wellbeing.

Today, work-life balance has become more and more a prevalent concern to both employers and employees of most organizations. Most recently, there has been an increase in the thought about the significance that work has on family as well as life of employees. Thus the situation has stimulated much study on work-life of individuals in the workplace. Especially, in today's global business environment, where there is a blur between work roles and personal roles. Work is no longer restricted to the office space due to advancements in technology, coupled with high level of competition originating largely from efforts to 
deliver excellent service, thus the encumbrance of work on employee personal life is usually enormous (Uzoechi \& Babatunde, 2012). Therefore, achieving work-life balance in this era of fast pace globalization and competitiveness as well as creating a balance between professional and personal life is a challenge for most individuals in the workplace (Sivatte, Gordon, Rojo, \& Olmos, 2015).

In the Nigerian context, the encumbrance of work roles on employee family roles is further heightened by demographic changes, an increase in the number of women in the workforce, dual career couples, a rise in the number of single parents, and employees' growing reluctance to accept long hours of work culture (Ogechi \& Nwaeke, 2019). Nigerian employees are thus faced with the challenge of prioritizing between work and non-work roles (Mmakwe \& Ojiabo, 2018), which results in work-family imbalance. Consequently, there is increased level of stress in employees, rising rate of drug abuse, decreased productivity, increased rate of turnover and absenteeism, decreased level of job satisfaction, etc. which influence employee performance (e.g. AlHazemi \& Ali, 2016). Also, high attrition rates and increasing demand for work-life balance have forced organizations to look beyond run of the mill Human Resources interventions (Mmakwe \& Ojiabo, 2018). In lieu of the foregoing, this paper examines the relationship between work-life balance and employee performance in the Nigerian workplace.

Work life balance has received a lot of attention in the West but far less attention has been devoted to it in Nigeria (Ojo, Falola and Mordi, 2014). This paper will focus on employees' consideration of the importance of their personal situations and organization welfare policies towards effective performance management on balancing their worklife. It seeks to review literature in assessing work life balance in Nigeria and suggest suitable solutions for overcoming the problem of work life imbalance and reduce stress which leads to encouraging the employee's optimal performance to enhance organizational output.

\section{LITERATURE REVIEW}

\section{THEORETICAL FOUNDATION}

\section{A. Spill Over Theory}

The spillover theory clearly explains the relationship between work life balance and employee performance. The theory assumes that individuals carry the values, emotions, attitudes, skills and behaviours that they establish in one domain of life into another domain (Piortrkowski, 1979; Belsky, Perry-Jenkins \& Crouter, 1985; Powell \&Greenhaus, 2010, Lakshmypriya \& Krishna, 2016), and that there is a similarity between what occurs in work environment and non-work environments that is why there is a spill over between these systems. There are two types of spill over; positive and negative spill over (Xu, 2009; Edwards \&Rothbard, 2000).

A positive spill over occurs when satisfaction and achievement in one domain may result in satisfaction and achievement in another domain. Several authors posit that experiences gained in an individual's activities in one domain can benefit his activities in another domain (e,g, Grywacz, Carlson, Kacmar \& wayne, 2007) and role expansion hypothesis (Mark, 1977) has been used to explain positive spill over. This hypothesis states that individuals generate resources like positive mood, skills and opportunities from the multiple roles they engage in and these in turn can be used in different life domains to improve their performance and enable growth. Negative spill over refers to difficulties and depression in one domain causing a corresponding emotion in another domain and studies have shown job demands to result in work life conflict and work overload (Geurts, Rutte \& Peeters, 1999; Demerouti, Bakker \&Bulters, 2004).

It posits that spill over between work and non-work environments, which is basically the transmission of experiences from work domain to non-work domain at the intra individual level, occur regularly and these experiences can be negative or positive. Hence to enhance positive spill over, there is need for employers tostrive to mitigate conflict between work roles and non-work roles through interventions like alternate work schedules and child and elderly care programmes and to also provide conducive work conditions and monitor how job demands influence family life (Bakker \& Demerouti, 2013) in order to mitigate negative spill over. Sirgy, Efraty, Siegel and Lee (2001) posit that spill over can be vertical or horizontal. Horizontal spill over shows how one life domain influences a neighbouring domain. The authors also posit that individuals rank life domains in a hierarchy in order of importance, ranging from super ordinate to subordinate domains, thus when spill over occurs from one hierarchy to another upwards or downwards, it is referred to as vertical spill over.

\section{B. Work-life Balance}

There is no consensus on the meaning of work life balance, as several authors have defined it in different ways. Barrera (2007) defined the concept as employers working constructively with their employees to put in place arrangements, which take into account the needs of the business as well as the non-work aspects of employees' lives. This definition clearly puts the responsibility of achieving balance on both the employer and the employee. However, some authors define it in a way that the responsibility of achieving balance is placed on the employee, e.g. Kirchmeyer (2000:80) defined it as "achieving satisfying experiences in all life domains and to do so requires personal resources such as energy, time and commitment to be well distributed across domains". Greenhaus, Collins and Shaw (2003:513) also define it as "the extent to which an individual is engaged in and equally satisfied with his or her work role and family role."

Haar, Russo, Sune and Ollier-Malaterre (2014) posit that it is an individual's assessment of how he balances multiple life roles effectively. All these definitions reveal that WLB is an interface of work and family, and many scholars have illustrated that the concept of work embraces the setting of formal tasks to be undertaken by employees in a bid to accomplish goals (e.g. Helmle,Botero, \&Seibold2014; Semlali\&Hassi,2016) and life is shown to relatively encompass an assortment of numerous activities which most often do not associate with work, for example 
activities such as house chores and childcare, in which case work-life balance is accomplished when there is existing harmony between work and life. For the purpose of this study, the definition by Barrera (2007) will be adopted.

Semlali and Hassi (2016), opine that since the last decades, the concept of work-life balance has been seen to be essential to both organizations and employees, and it has without a doubt been established to significantly impact in the enhancement of employee's throughput which goes a long way in impacting on the overall performance of organizations in a positive manner (Guthrie, 2012). Effective work-life balance policies that are currently being embraced by organizations permit the employees to interact and socialize with the rest of community while guaranteeing that cost and hiring and firing rates are kept under control leading to improvement in productivity (Helmleet al., 2014). Presently, in a bid to fine-tune the organizational structures to the needs of the employees or in response to government regulations with respect to gender equality, integration, and protection of families, a lot of organizations dedicate their resources to the ingenuities of work-life balance (Susana \& Ramón 2013). According to Ogechi and Nwaeke (2019), Nigerian organisations in the oil sector are currently changing organizational culture and programs and initiating measures designed to reduce work life conflict and improve staff effectiveness at work and other roles. By doing this effectively, such organizations are likely going to groom a collection of employees that enjoy work-life balance and in turn show more dedication towards the attainment of organizational goals.

Most of the focal point in studying work life balance has been the effect of organizational policies that are developed to provide necessary assistance to employees geared towards diminishing the conflicts that exist between employee's work in an organization and life in both the organization and at home(societal life inclusive). Consequently, it is not surprising that management literature has at various times made concerted efforts to appreciate the role played by organizations to help diminish the conflict experienced by employees resulting from the demands of work and the part they are required to play at home(Hon \& Chan, 2013). This efforts are noble, viewing it from the standpoint that the ability to use work-life balance mechanism to decline incidences of grievances in organization will impact on the frequency of conflicts and enhance workplace harmony that we view as an instrument that elicits workers performance It has been established from relevant research findings that, employees with access to such services as flexible schedules, childcare, parental leave, and support from supervisor seem to be more likely have less incompatible work-life, greater job satisfaction, less stress, and are less disposed to turnovers (Helmle et al., 2014).

In the quest to understand or appreciate the issues surrounding work-life balance gender has also been explored, mostly with regards to how the roles and potentials of gender impacts the achievement of balance between work and family roles. We believe that the outcomes from research findings regarding gender expectations in many circumstances usually impact on individual insight towards the conflict between work and life roles. This can escalate the perceived level of stress and the perceptions of conflict in relation to the roles of work and life to increase performance (Helmle et al., 2014; Lawson, Davis, Crouter\& O'Neill, 2013). In a patriarchal society such as Nigeria, it is more demanding for employees, especially women, to achieve balance, as societal expectations with respect to commitment to family put women in a situation where there is constant conflict between their work and family roles (Mordi, Simpson, Singh, \&Okafor,2010).

The management of work-life balance of employees have been found to be among the primary focus for organizations to address in a bid to develop ways to help preserve human resources (Au \& Ahmed, 2014). Human access which is fundamental to the success of organizations needs to be harnessed and catered for in a bid to improve organizational well-being too. The preservation of human resources has become an essential practice in today's organizations as a result of skyrocketing competitiveness in the business environment. However, Work-life balance incorporates a balance between two exclusive roles undertaken by a person such as work and family roles, of which the effective management of both bring about increase in satisfaction and performance (Shaffer, Reiche, Dimitrova, Lazarova, Chen, Westman, \&Wurtz, 2016). On the other hand, it is worthy to emphasize that the benefits of work-life balance can enhance both the life quality of employees and the effectiveness of the organization. Therefore, it is also essential to note the fact that, there appears to be limitless explanations of work-life balance, but all appear to be in agreement that work entails a group of formal tasks completed by an individual or group while occupying a given job position and that life comprises a group of activities not associated with work such as household chores, care of elders and care of children (Anwar,Hansu, \&Janjua, 2013). Work-life balance is about a person's capacity irrespective of age or gender to successfully combine both work and household accountabilities. This paper discusses three dimensions of work life balance thus:

\section{Flexi-time Schedules}

Flexible working hours, flexi-time or flexible schedules are commonly used and quite extensively studied. Flexible working arrangements are usually made between employer and employee in which they agree to schedule the work flexibly, aiming to gain benefits to both parties as evidenced from findings, employees with access to services including flexible schedules, childcare, parental leave, and support from supervisor appear to be more likely have less conflicting work-life, greater job satisfaction, less stress, and are less inclined to want to quit (Helmleet al., 2014). Employees have to muddle through increased role demands and new technology has also made it possible to communicate and work wherever and whenever, thus managing multiple roles as individuals has become even more difficult (Rothbard, Phillips \& Dumas, 2005). Also, the likelihood and anticipation to work unusual times has created health risks (Greubel,Arlinghaus, Nachreiner, \& Lombardi, 2016). In their study based in Nigera, OgechiandNweke (2019) found that the main cause of work life and family conflict in the oil sector of the Niger Delta Region is the absence of flexible work schedule and excessive working hours. In organizations where employees work in an un-flexible environment, the tendency that they will develop stress and role conflict is usually on 
the increase. Organizations adopt more flexible work arrangements in order to respond to the needs and expectations of employees. In reality however, flexibility favours more organizations than employees since with flexible working hours, employees may spend more time working (Wheatley, 2016). Flexible working hours are strongly linked to work-family enrichment (Rastogi, Rangnekar \& Rastogi, 2015). This allows employees to choose favourable times for them to work effectively. As Zülch, Stock and Schmidt (2012) stated, employees perceive flexible working hours as essential, especially, when striking a good work-family balance. Flexi-time promotes employee's work-life balance and wellbeing because it reduces work-life conflict, pressure and stress (Wheatley, 2016)

\section{Work Leave Initiatives}

Leave is the number of days or hours an organisation permits an employee to be away from work within a period of time without consequences (Orogbu, Onyeiugbe, \& Chukwuemeka, 2015). Leave initiatives are best applied at the beginning of each calendar year so as not to interrupt the smooth running of the organization as well as avoid conflicting situations. Leave programmes cut across various individuals and aspects in the workplace, it includes annual vacation, parental leave, casual leave, medical leave, compassionate leave, study leave, career leave etc. In Nigeria, Section 18 of the Labour Act, 1990 provides that upon completing a qualifying period of service of 12 months continuous service, employees are entitled to annual leave with pay for the purpose of rest and/or recreation and every organisation is compelled to implement this policy as noncompliance will be tantamount to disobedience to the rule of law in the country. However, annual leave may be deferred on agreement between both parties (the organisation and the employee), but not beyond 24 months continuous service. Isaacs, Healy and Peters (2017), assert that paid leave policies also affect a family's finances after childbirth, through the direct payment of leave and increased likelihood of mothers remaining in the labour force. Stanczyk (2016) opines that California's paid leave program reduces a mother's risk of poverty following a birth, particularly among disadvantaged mothers.

Another aspect of leave initiatives is parental leave, Oludayo, Gberevbie, Popoola, andOmonijo, (2015), view parental leave as an official permission granted employees burdened with child caregiving responsibilities, it includes maternity leave, the Nigerian Labour Act, 1990 also provides for maternity leave in Part III, Section 54,it is usually more beneficial to female employees and allows nursing mothers to stay away from work for twelve weeks sixweeks before and six weeks after confinement. On health grounds, Section 16 of the Nigerian Labour Act, 1990provides for sick leavewhich permits absence from work in order to attend to dependent care challenges or personal health concerns of the employee.

\section{E. Informal Support}

Informal initiatives/support is the support given by family members, colleagues and supervisors to decrease the load and or stress of work-life interface and which is not part of written rules and regulations. In their study, Suifan,
Abdallah and Diab (2016), viewed informal WLB practices and managerial support and job autonomy had the most significant effect and are the determinants of turnover intentions. Employees that lack informal support tend to exit and seek employment in a better organization. According to Suifan et al., (2016), managerial support is also another key informal WLB practice which refers to the extent to which managers' support and appreciate their subordinates as regards their personal and family life issues. Managerial support is expected to considerably improve satisfaction among employees (Abdallah, Anh, \& Matsui, 2016).

Managerial support is crucial to secure employee commitment to set concrete actions in motion and for successful implementation in the workplace. Emhan (2012) opines that the commitment of employees to their organization increases as a result of managerial support and job satisfaction. When the level of employee commitment is affected positively and contributes to decline in the number of employee turnover. Across all kinds of organizations, whether non-profit or profit oriented, there is a common need which is effective management or the need for managers to possess the motivating ability towards their employees and managerial support targeted at the employees plays a crucial role in achieving it. Furlich (2016) asserts that one of the ways through which organizations can increase their productivity, efficiency and employee satisfaction is employee motivation. Recognizing how important motivation is to employees for maximum output, he suggested that managers should be provided training sessions which would help to create in them, the awareness of the effect of human relation in terms of communicating with employees has on their motivation, which reflects an increase in productivity. The understanding of employee motivation can tremendously influence an organization. When employees are motivated, the potential for them to work harder and become more satisfied with their job increases compared to demotivated employees (Elias, Smith \& Barney, 2012). Motivation has the capacity to increase job performance effectively and efficiently. The expectancyvalence theory validates this thought. It is a theory focused on motivation based upon the choices an individual makes when striving for a goal, taking into account the expectations of an individual when understanding their anticipated motivation. Employee expectations can often be influenced by their supervisor (Yuan \& Woodman, 2010). The expectancy-valence theory is important for investigating motivation because the overall context of the interactions between supervisors and employees is important to understand, which include employee expectations (Yuan \& Woodman, 2010).

\section{F. Work Life Balance in Nigeria}

According to Mmakwe and Ojiabo (2018) multi-faced demand between work and home responsibilities have assumed increased relevance for employees in the Nigerian work environment in recent years and this is due to demographic and workplace changes, such as; transformation in family structures, growing reluctance for long number of hours acceptance culture, greater number of women in the workforce and technological advancement. All these have resulted in the employees having difficulty in prioritizing between their work roles and their personal lives. Consequently, scholars have carried out studies of the 
concept of work life balance in Nigeria, even though it is still at an elementary stage in its development in the country (Adisa, Mordi, \&Osabutey, 2017) and some of these recent studies will be examined as follows.

In his work titled 'Realities of Work Life Balance in Nigeria: Perceptions of Role Conflict and Coping Beliefs' Akanji (2012) explored the perceptions of WLB practices in Nigeria. The author adopted a qualitative approach in which 61 in-depth interviews of Nigerian employees comprising 41 female and 20 male employees from service based organisations (banking, telecommunications and motor insurance companies) in Lagos State were conducted. The study adopted the Grounded theory approach for data analysis processes which aims to discover theory from the data systematically obtained from this research. Participants in this study attributed the primary sources of their work-life conflict situations to the political, economic and social challenges facing Nigeria, suggesting that "conditions outside an organisation and an individual's sphere of life has a sizeable impact at influencing the fundamental realities derived from an individual's capacity of co-ordinating obligations at work and family levels with minimal conflict." (2012: 255). The author posits that Nigeria's culture of corruption, high unemployment ratios, poverty, inflation, and patriarchy are sources of work-life conflict for her workers. Results also showed that role overload was another major source of work-life conflict for Nigerian women given that Nigeria's status as a patriarchal society thrusts women into a position where family commitments come into serious conflict with other roles. The author identified personal hardiness, assistance seeking solutions, and avoidance/resignation as coping strategies adopted by Nigerian workers. He posits that employers of labour easily circumvent the ideals of WLB practices and policies because of a lack of institutionalised social support systems, disregard for a culture that encourages WLB solutions and effectual enforcement of employment standards by the national government.

Ojo, Salau and Falola (2014) in 'Work-Life Balance Practices in Nigeria: A Comparison of Three Sectors' carried out a study on WLB policies and practices in the Banking, Educational and Power Sectors of the Nigerian Economy. They investigated the policies and practices of WLB existing in these sectors and also identified the various hurdles that hinder the implementation of these policies. Quantitative method was used and they relied on a case study analysis to identify existing WLB practices in these sectors. Questionnaires were administered and items on the questionnaire were adapted from Hooker, Neathy, Casebourne, and Munro (2007). A total of 1,624 questionnaires were retrieved, comprising Banking sector 586, Educational sector 531 and Power sector 507. Data analysis was done with the Statistical Package for Social Sciences, including Anova. The findings of this study showed a wide gap between WLB practices and employees' understanding of the implementation of WLB policies in the sectors studied. The authors posit that there is a general belief among workers that WLB policies and practices are mainly for the female folk as most of the initiatives are inclined towards women, e.g. Maternity leave and childcare arrangements. However, this is not the case, as these arrangements are available for male employees as well.
They were able to identify most of the initiatives that are available in western literature in these sectors, except some others like job share, annualised hours and compressed hours which they attributed to workers' preference for conventional full time permanent contracts. They also identified barriers to implementation of WLB initiatives in these organisations as long hours of work culture, increased work demands, and lack of support from line managers. The results showed the percentage of usage of the available WLB initiatives to be very poor, the authors attributed this to an organisational culture that is unsupportive of WLB initiatives thus leading to managers and employees reluctance to utilise those initiatives.

Akanji, Mordi and Ojo (2015) undertook a study titled 'Reviewing Gaps in Work-Life Research and Prospecting Conceptual Advancement' in which they examined the concept of work life balance by reviewing extant literature. As part of this study, the authors conducted a fieldwork between January to May, 2015 in which they highlighted the perspectives of work life conflict realities in Nigeria by interviewing 50 Nigerian middle-line management employees working in service management organisations. This qualitative study revealed that the provision of types of work life balance policies at the managerial level were weak and this was largely the cause of work life conflict in the Nigerian context. The study further revealed some reasons for the lack of WLB policies to be "high level of unemployment, fear of job loss, lack of WLB awareness, government insensitivity and organisational focus on performance and profits at the expense of employee wellbeing" (2015:25). The authors proposed the following conditions that can enhance the adoption of WLB practices in the Nigerian context; flexible work arrangements to be enforced by government legislations that will statutorily empower employees to request for atypical work patterns, raising the awareness of organisations to the advantages of protecting workers' rights to various leave initiatives that will improve employee wellbeing, provision of dependent care facilities by organisations especially, for working mothers and managerial training to ensure managerial support for the demands of these policies.

Mushfiqur, Oruh, Nwagbara, Mordiand Turner (2018) conducted a study titled 'The Impacts of Work Life Balance Challenges on Social Sustainability: The Experience of Nigerian Female Medical Doctors' in which they examined the implications of WLB challenges for Nigerian female doctors. Qualitative interpretivist approach was adopted in this study which explored how Nigeria's institutional environment and workplace realities give rise to WLB challenges. The authors carried out 43 semi-structured interviews and focus group discussion sessions involving 8 participants. This study viewed the concept from a nonwestern context and results revealed that work pressure, cultural expectations, unsupportive relationships, challenging work environment, gender role challenges, lack of participation and high stress level moderate the ability of female medical doctors to achieve WLB.

\section{G. Employee Performance}

It is no longer new that organizations spend chunks of their resources to empower their employees in a bid to bring out their best. This is usually done through trainings and 
developments, thus, the employees having acquired these trainings become valued asset for the organization. However, no organization likes losing such highly priced assets to competitors, rather they retain such employees in the organization unless they are not satisfied with their job outputs (Gitongu, Kingi \& Uzel, 2016). Thus, organizations are required to focus more on the drives that enhances employees' job satisfaction and trainings to stimulate enhanced performance from them (Gruman\& Saks, 2011). Most organizations are seen in recent times to focus on dynamics that promote and enhance employees' performance since it has a direct link with the goal attainment drives of organizations.

Employees' performance signifies the efficiency level as well as the productivity of individuals leading towards organizational goal attainment as a result of their positive contribution which ultimately results in the overall performance of the organization (Markos \& Sridevi, 2010). According to Anitha (2014), organizations have recently realized the consequence of enhanced employees' performance as organizations' goals cannot be achieved unless employees' performance is above board. Increased employee output therefore is essential in the accomplishment of such organizational goals as increased customer satisfaction, market share, market expansion and profitability.

Faiza and Nazir(2015), describes employee performance as responses in the form of behaviours reflecting what has been learned by the employee or the kind of training that the employee has obtained. This is to say that, it entails the outcome of both mental and psychological capabilities of individuals. Employee Performance as a concept has increasingly taken the centre stage of discourse amongst scholars of management sciences, as employee performance is of the essence to both individual and the organization. Employee Performance supports the overall enhancement of the processes of the organization particularly in terms of efficiency and productivity (Masa'deh, Alrowwad, Alkhalafat, Obeidat \&Abualoush, 2018). Notably, employee performance is not always seen as the end outcomes but it entails all the efforts that employees put in the process leading to the attainment of organizational goals. Employee performance as viewed by some authors has connection with the activities and tasks employees undertake in an effective and efficient manner, and it also dictates how much employees contribute to the organization and among the contributions of employees are output quantity, work attendance, and accommodating attitude (Masa'deh et al., 2018).

With regards to the idea of performance, it can be measurable using different mechanisms, but in general, performance encompasses what is done or not done by employee. It entails the full outcome or success of a person during specific periods of duty as opposed to the predetermined and established standard of work and targets or criteria (Faiza \& Nazir, 2015;Masa'deh et al., 2018; Pawirosumarto, Sarjana \& Gunawan, 2017). Performance is the outcome of the employees capability, dexterity, multiplied with support from supervisor and effort put in at work. Hence, performance will witness decline if the employee lacks capacity, supervisory support or ability to put in necessary effort. Employee job performance has always been a major challenge in organizational management and adopting effective ways to motivate employees to achieve and deliver higher job performance as well as increase the organizational competitiveness is one of the main objectives of every business organization (Lee \& Wu 2011).

However, Ogbulafor (2011), had advocated that the declining level of employee performance in Nigerian organizations has become a serious threat to the survival of most organization in Nigeria and needs to be attended to immediately. This study supports the advocacy of the author as we believe that employee performance is influential to organizational growth and profitability. The employees are regarded as the major business resource that facilitate the daily activities and operations of an organization (Muda, Rafiki \& Harahap, 2014). According to Mowday, Porter and Steers (2013), most employees of today have a high degree of job dissatisfaction which create attitudes that are undesirable on the job and in turn degenerate their performance ability and that of the organization in the long run.

Employee job performance has always been an important concern for managers of organizations (Kelidbari, Dizgah, \&Yusefi, 2011). According to Ahmad and Shahzad (2011), seemingly, employee performance exemplifies the whole belief of the employee about their behaviour and involvement toward the accomplishment of the organizational goals, and additionally stated that compensation practices, performance evaluation and promotional practices are effective determining factors of employee performance. These determinants of employee performance only focus on tangible benefits to the employees. Similarly, Anitha, (2014), described employee performance as an indicator of financial or other outcome of the employee that has a direct connection with the performance of the organization as well as its accomplishment. The author further revealed that work atmosphere, leadership, team and co-worker relationship, training and career development, reward programme, guidelines and procedures and workstation wellbeing as well as employee engagement are major factors that determine employee performance.

However, a study conducted by Alagaraja and Shuck (2015), aimed at discovering the prevailing viewpoints of organizational configuration and employee engagement in order to understand reasons associated with enhancing individual performance argue that employee performance can be enhanced through training and development. Therefore, employee performance brings to bare innovative performance and firm performance as a whole, in such a way that successful effort of fulfilled, inspired, and devoted human resources produce innovative ideas for new products or services and increase quality performance, operational performances, and client satisfaction directly (Sadikoglu \& Zehir, 2010). It is important to note, that globalization has created a lot of alterations and challenges that impact most organizations around the world and Nigerian organizations are not exempted from this situation. Employee performance is among the critical factors that contribute significantly to organizational success. Learning organizations play an 
important role in enhancing employee performance through providing trainings and developments for their employees (Gitongu et al., 2016).

\section{H. Work-Life Balance and Employee Performance}

In this era of technological advancement and globalization, there is an increased concern on how an individual could manage to have satisfactory personal life while at the same time delivering excellent results at work. This has propelled scholars to unravel whether both goals are incongruous or complement one another (Koubova \& Buchko, 2013).The observed difficulty faced while attaining the correct balance with regards to effort of individuals and benefits associated with it has significant relationship to the absence of control over workload as well as lack of energy in fulfilling personal needs and obligation. According to Johari et al.(2018),when there is inequity between sweat and reward, fatigue, poor performance and a decline of quality of life sets in. Generally, there are three primary concerns pertaining to work-life imbalance in the workplace in view ofthe fact that it is affected by technological advancement in recent times. The first concern is on the advances at work which can be hazardous to work life balance, another being the fluctuating nature of work activities, predominantly, tasks that are related with technology which entails continuous improvement in knowledge, and finally anxieties regarding shifting work demands (Helmleet al., 2014).

It is just unfortunate that some supervisors are reluctant to employ flexible arrangements, due to impulsiveness and potential abuse of these procedures (Hon \& Chan, 2013; Susana \& Ramón, 2013). Work-life balance has implication on the attitudes, behaviours and wellbeing of employees as well as the effectiveness of the organization. Au and Ahmed (2014), opine that companies are indulged to incorporate new management procedures that provide collective and managerial support. The perceptions of superiors towards their employee work-life conflict also greatly dictate the career progress of employees ( $\mathrm{Au} \& \mathrm{Ahmed}, 2014)$. In the last few years, the issue of work-life balance has been heavily scrutinized particularly in terms of increasing the flexibility of paid work and improvements in working conditions. In this regard, employees with heavy workloads were reported to have low work life balance, were less likely to be embedded within their jobs while also demonstrating poor job performance. Relevantly, stress is also a dimension of personal employee similar to emotional exhaustion, and among hotel employees, stress has been reported to affect their quality of life (Lawson et al., 2013). Additionally for hotel employees, the spill-over of stress has been viewed to exacerbate the stress on work life balance. (Hon \&Chan 2013).

In the perspective of organizations and people, work life balance has established its significance since the past decades. Work life balance has without a doubt been found to be the major contributory factor in the productivity enhancement of employees and this has a positive influence on the general performance of organizations (Semlali \& Hassi, 2016; Mmakwe \& Ojiabo, 2018). In their study of WLB and employees job performance in Nigeria, Ogechi and Nwaeke (2019) found part time working and delegation of duties to enhance employees' task completion.
Organizations need to implement an effective work-life balance policy, that is, a policy that will allow employees to remain socially connected with society while cost and turnover are controlled, and productivity is improved (Helmle et al., 2014).

\section{CONCLUSION}

It is evident from this review that employees who have balanced work and non-work roles are more likely to perform better thus, it is essential for employers to promote policies and structures that enhance work life balance of employees in their organisations. However, in the Nigerian context, several studies have shown that there are systemic barriers that hinder the implementation of work life balance policies, such as leadership failure which has birthed political, economic and social challenges that are the primary sources of work life conflict, they include corruption, weak institutions that lack the capacity to monitor and enforce employment standards, high unemployment ratios, poverty, inflation and a plethora of others.

The studies also showed other barriers that are more directly hindering the successful implementation of WLB policies in organisation to include role overload, long hours of work culture, lack of supportive organisational culture, reluctance to accept available WLB policies, a wide gap between WLB practices and employees' understanding of the implementation of these policies, etc. With all these challenges at play, it is evident that even though there are available WLB policies in organisations, successful implementation has been very poor, there is therefore need for scholars to research on ways in which organisations can assist employees to achieve WLB in order to improve their performance and productivity.

\section{RECOMMENDATIONS}

We recommend that organisations provide flexible work arrangements to be enforced by government legislations that will statutorily empower employees to request for atypical work patterns, that the awareness of organisations be raised to the advantages of protecting workers' rights to various leave initiatives that will improve employee wellbeing, and provision of dependent care facilities by organisations especially, for working mothers and managerial training to ensure managerial support for the demands of these policies. In addition, organisations should provide supportive organisational culture and educate employees to fully understand available WLB policies, practices and implementation in order for them to take full advantage of such policies.

\section{REFERENCES}

Abdallah, A.B., Anh, P.C., \& Matsui, Y. (2016).Investigating the effects of managerial and technological innovations on operational performance and customer satisfaction of manufacturing companies. International Journal of Business Innovation and Research, 10(2), 153-183.

Adisa, T.A., Mordi, C. \&Osabutey, E. L. C. (2017).Exploring the implications of the influence of organizational culture on work life balance practices: Evidence from Nigerian medical doctors.Personnel Review, 46(3), 454-473.

Ahmad, S., \&Shahzad, K. (2011). HRM and employee performance: A case of university teachers of Azad Jammu and Kashmir (AJK) 
in Pakistan. African Journal of Business Management, 5(13), 5249 .

Akanji, B., Mordi, C., \&Ojo, S, (2015). Reviewing gaps in work-life research and prospecting conceptual advancement. Economic Insights - Trends and Challenges, 4(68) 21-30.

Akinjide, B. (2012). Realities of work life balance in Nigeria: Perceptions of role conflict and coping beliefs. Business Management and Education 10(2), 248-263.

Alagaraja, M., \& Shuck, B. (2015).Exploring organisational alignment employee engagement linkages and impact on individual performance: A conceptual model.Human Resource Development Review, 14(1), 17-37.

AlHazemi, A. A., \& Ali, W. (2016). The notion of work life balance, determining factors, antecedents and consequences: A comprehensive literature survey. International Journal of Academic Research and Refection, 4(8), 74-85.

Anitha, J. (2014). Determinants of employee engagement and their impact on employee performance.International Journal of Productivity and Performance Management, 63(3), 308-323.

Anwar, J., Hansu, S. A. F., \&Janjua, S. Y. (2013). Work-life balance: What should organisations do to create balance?World Applied Sciences Journal, 24(10), 1348-1354.

$\mathrm{Au}$, W. C. \& Ahmed, P.K. (2014). Sustainable people management through work-life balance: A study of the Malaysian Chinese context. Asia-Pacific Journal of Business Administration, 6(3), $262-280$.

Bakker, A. B. \&Demerouti, E. (2013).The spillover-crossover model. In J. G. Grzywacz\& E. Demerouti (Eds.), Current issues in work and organisational psychology: New frontiers in work and family research, (55-70), New York, NY, US: Psychology Press.

Barrera, S. (2007).Work life balance: From rhetoric to reality. Retrieved October 19, 2019, from http://www.docep.wa.gov.au/WorkSafe/PDF/Forums/worklife_ balance.pdf

Belsky, J., Perry-Jenkins, M., \&Crouter, A. (1985). The work family interface and marital change across the transition to parenthood. Journal of Family Issues, 6, 205-220.

Demerouti, E., Bakker, A. B, \&Bulters, A. (2004). The loss spiral of work pressure, work-home interference and exhaustion: Reciprocal relationships in a three-wave study. Journal of Vocational Behaviour, 64, 131-149.

Edwards, J. R. \&Rothbard, N. P. (2000). Mechanisms linking work and family: Clarifying the relationship between work and family constructs. Academy of Management Review, 25, 178-199.

Elias, S. M., Smith, W. L., \& Barney, C. E. (2012). Age as a moderator of attitude towards technology in the workplace: Work motivation and overall job satisfaction. Behaviour \& Information Technology, 31(5), 453-467.

Emhan, A. (2012). Relationship among managerial support, job satisfaction and organisational commitment: A comparative study of non-profit, for profit and public sectors in Turkey. International Journal of Business and Technology, 2(5), 179190 .

Faiza, T. A., \&Nazir, F. S. (2015). Capacity building boost employee performance. Industrial and Commercial Training, 47(2), 6166

Furlich, S. A. (2016). Understanding employee motivation through managerial communication using expectancy-valence theory.Journal of Integrated Social Sciences, 6(1), 17-37.

Geurts, S. A. E., Rutte, C., \&Peeters.M. (1999).Antecedents and consequences of work-home interference among medical residents.Social Science \& Medicine, 38, 1135-2248.

Gitongu, M. K., Kingi, W. K., \&Uzel, J. M. (2016). Determinants of employees' performance of state parastatals in Kenya: A case of Kenya Ports Authority. International Journal of Humanities and Social Science, 6(10), 197-204.

Greenhaus, J. H., Collins, K. M., \& Shaw, J. D. (2003). The relation between work family balance and quality of life.Journal of Vocational Behaviour 63, 510-531.

Greubel, J., Arlinghaus, A., Nachreiner, F., \& Lombardi, D. (2016). Higher risks when working unusual times? A cross-validation of the effects on safety, health and work-life balance. International
Archives of Occupational and Environmental Health, 89(8), 1205-1111.

Gruman, J. A., \& Saks, A. M. (2011).Performance management and employee engagement.Human Resource Management Review, 21(2), 123-136.

Grzywacz, J. G., Carlson, D. S., Kacmar, K. M., \& Wayne, J. H. (2007).A multi-level perspective on the synergies between work and family.Journal of Occupational and Organisational Psychology, $80(4), 559-574$.

Guthrie, V. M. J. (2012). Management control of work-life balance.A narrative study of an Australian financial institution.Journal of Human Resource Costing \& Accounting, 16(4), 258-280.

Grzywacz, J. G., \& Carlson, D. S. (2007).Conceptualising work-family balance: Implications for practice and research.Advances in Developing Human Resources, 9(4), 455-471.

Haar, J. M., Russo, M., Sune, A., \&Ollier-Malaterre, A. (2014). Outcomes of work-life balance on job satisfaction, life satisfaction and mental health: A study across seven cultures. Journal of Vocational Behaviour, 85, 361-373.

Helmle, J. R., Botero, I. C., \&Seibold, D. R. (2014).Factors that influence work-life balance in owners of copreneural firms.Journal of Family Business Management, 4(2), 110-132.

Hon, A. H. Y. \& Chon, W. W. (2013).The effects of group conflict and work stress on employee performance.Cornell Hospitality Quarterly, 54(2), 174-184.

Hooker, H.,Neathey, F., Casebourne, J., \& Munro, M. (2007).The third work balance employee survey: Main Findings. Department of Trade and Employment Relations Research Series No.58. London: DTI.

Hyde, P., Sparrow, P., Boaden, R., \& Harris, C. (2013). High performance HRM: NHS employee perspectives. Journal of Health Organization and Management 27(3), 296-311.

Isaacs, J., Healy, O., \& Peters, H. E. (2017).Paid family leave in the United States: Time for a new national policy.Urban Institute, May, $2017 . \quad$ Available at: https"//www.urban.org/sites/default/files/publication/90201/paid _family_leave_O.pdf. Accessed $21^{\text {st }}$ October, 2019.

Johari, J. Yean Tan, F., \&TjikZulkarmain, Z. I. (2018). Autonomy, workload, work-life balance and job performance among teachers.International Journal of Educational Management, 32(1), 107-120.

Kelidbari, H. R., Dizgah, M. R., \&Yusefi, A. (2011). The relationship between organisational commitment and job performance of employees of Guilin Province social security organisation. Interdisciplinary Journal of Contemporary Research in Business, 3(6), 555.

Kirchmeyer, C. (2000). Work life initiatives: Greed or benevolence regarding workers' time. In C. L. Cooper and D. M. Rosseau (Eds.) Trends in Organisational Behaviour, 7, 79-93. Chichester; John Wiley \& Sons.

Kossek, E. E., Valcour, M. \&Lirio, P. (2013): The sustainable workforce: Organisational strategies for promoting work life balance and wellbeing. In Work and wellbeing: A complete reference guide Edited by Peter Y. Chen and Cary L. Cooper. (C) 2014 John Wiley \& Sons, Ltd.Accessed October, 2019. DOI: 10.1002/9781118539415.wbwell14.

Koubova, V., \&Buchko, A. A. (2013). Life-work balance: Emotional intelligence as a crucial component of achieving both personal life and work performance. Management Research Review, 36(7), 700-719. 
Lakshmypriya, K. \& Krishna, G. R. (2016). Work life balance and implications of spill over theory: A study on women entrepreneurs. International Journal of Research in IT and Management 6(6), 96-108.

Lawson, K. M., Davis, K. D., Crouter, A. C., \& O’Neill, J. W. (2013). Understanding work-family spill over in hotel managers. International Journal of Hospitality Management, 33, 273-281.

Lee, F., \& Wu, W. (2011).Moderating effects of technology acceptance perspectives on e-service quality formation: Evidence from airline websites in Taiwan.Expert Systems with Applications, 38(6), 7766-7773.

Mark, S. (1977). Multiple roles and role strain: Some notes on human energy, time and commitment. American Sociological Review, 42, 921-936.

Markos, S., \&Sridevi, M. S. (2010). Employeeengagement: The key to improving performance. International Journal of Business and Management, 5(12), 89-96.

Masa'deh, H., Alrowwad, A., Alkhalafat, F., Obeidat, B., \&Abualoush, S. (2018). The role of corporate social responsibility in enhancing firm performance from the perspective of IT employees in Jordanian banking sector: The mediating effect of transformational leadership. Modern Applied Science, 12(7), 126.

Mmakwe, K. A., \&Ojiabo, U. (2018). Work life balance and employee performance in Nigerian banks, Port Harcourt. International Journal of Advanced Academic Research in Social and Management Sciences, 4(1), 107-119.

Mordi, C., Mmieh, F., \&Ojo, S. I. (2013). An exploratory study of managers' perspective of work life balance in Nigeria: A case analysis of the Nigerian banking sector. Thunderbird International Business Review, 55(1), 55-75.

Mordi, C., Simpson, R., Singh, S., \&Okafor, C. (2010).The role of cultural values in understanding the challenges faced by female entrepreneurs in Nigeria.Gender in Management: An International Journal, 25(1), 5-21.

Mowday, R.T., Porter, L.W., \& Steers, R. M. (2013). Employeeorganisation linkages: The psychology of commitment, absenteeism, and turnover. Academic Press.

Muda, I., Rafiki, A., \&Harahap, M. R. (2014). Factors influencing employee's performance: A study on the Islamic Banks in Indonesia. International Journal of Business and Social Science, 5(2), 73-79.

Mushfiqur, R., Mordi, C., Oruh, E., S., Nwagbara, U., Mordi, T., \& Turner, I. M. (2018). The impacts of work-life balance challenges on social sustainability. Employee Relations, 40(5), 868-888.

Nwagbara, U.,\&Akanji, B. O. (2012). The impact of work life balance on the commitment and motivation of Nigerian women employees. International Journal of Academic Research in Business and Social Sciences, 27(1), 38-47.

Ogechi, E. B.,\&Nwaeke, L. I. (2019).Assessment of work-life balance and employees' job performance in oil servicing companies in the Niger Delta region of Nigeria. IIARD International Journal of Economics and Business Management, 5(3), 33-42.

Ogbulafor, C. (2011). Motivation and job performance of academic staff of state universities in Nigeria: The case of Ibrahim Badamasi Babangida University, Lapai, Niger State. International Journal of Business and Management, 7(14), 142.

Ojo, I. S., Salau, O. P., \&Falola, H. O. (2014). Work-life balance practices in Nigeria: A comparison of three sectors. Journal of Competitiveness, 6(2), 3-14.

Oludayo, O. A., Gberevbie, D. E., Popoola, D., \&Omonijo, D. O. (2015). A study of multiple work-life initiatives in banking industry in Nigeria.International Research Journal of Finance and Economics, 133, 108-125.

Opatha, H. H. D. N. P., \&Arulrajah, A. A. (2014).Green human resource management: Simplified general reflections. International Business Research, 7(8), 101-112.

Orogbu, L.O., Onyeiugbe, C. U., \&Chukwuemeka, D. N. (2015).Work-life balance and employee performance in selected commercial banks in Lagos State.European Journal of Research and Reflection in Management Sciences, 3(4), 63-77.

Pawirosumarto, S., Sarjana, P., \&Gunawan, R. (2017).The effect of work environment, leadership style, and organisational culture towards job satisfaction and its implications towards employee performance in Parador Hotels and Resorts,
Indonesia.International Journal of Law and Management, 59(6), 1337-1358.

Piotrkowski, C. (1979). Work and the family system: A naturalistic study of working class and lower middle class families. New York: The Free Press.

Powell, G. N. \&Greenhaus, J. H. (2010). Sex, gender and the work-tofamily interface: Exploring negative and positive interdependencies. Academy of Management Journal, 53(3), 513-534.

Rachmaliya, N. S. \&Efendy, H. (2017): Analysis of employee performance, organisational culture, work satisfaction and organisational commitment. Human Resource Research, 1(1), 2329 - 9150.

Rastogi, M., Rangnekar, S., \&Rastogi, R. (2015).Flexibility as a predictor of work-family enrichment. Global Journal of Flexible Systems Management, 17(1), 5-14.

Rothbard, N., Phillips, K., \& Dumas, T. (2005).Managing multiple roles: Work-family policies and individuals' desires for segmentation.Organisation Science, 16(3), 243-258.

Sadikoglu, E., \&Zehir, C. (2010).Investigating the effects of innovation and employee performance on the relationship between total quality management practices and firm performance: An empirical study of Turkish firms. International Journal of Production Economics, 127(1), 13-26.

Semlali, S. \&Hassi, A. (2016). Work-life balance: How can we help women IT professionals in Morocco? Journal of Global Responsibility, 7(2), 210-225.

Shaffer, M. A., Reiche, B. S., Dimitrova, M., Lazarova, M., Chen, S., Westman, M., \&Wurtz, O. (2016). Work and family role adjustment of different types of global professionals: Scale development and validation. Journal of International Business Studies, 47(2), 113-139.

Sirgy, M. J., Efraty, D., Siegel, P., \& Lee, D. (2001).A new measure of quality of work life based on need satisfaction and spill over theories. Social Indicators Research, 55, 241-302.

Sivatte, I. de, Gordon, J. R., Rojo, P., \& Olmos, R. (2015). The impact of work-life culture on organizational productivity. Personnel Review, 44(6), 883-905.

Stanczyk, A. B. (2016). Paid family leave may reduce poverty following a birth: Evidence from California. Research Brief, Chicago, IL. Employment Instability, Family Well-Being and Social Policy Network, University of Chicago.Retrieved from http://cpb-usw2.wpmucdn.com. Accessed 21xt October, 2019.

Suifan, T. S., Abdallah, A. B., \&Diab, H. (2016). The influence of work life balance on turnover intention in private hospitals: The mediating role of work life conflict. European Journal of Business and Management, 8(20), 126- 139.

Sung, S. Y. \& Choi, J. N. (2012).Effects of team knowledge management on the creativity and financial performance of organizational teams.Organisational Behaviour and Human Decision Processes 118(1), 4-13.

Susana, P., \& Ramon, V. C. (2013).Work-life balance under challenging financial and economic conditions.International Journal of Business Studies, 7(1), 129-146.

Thevanes, N., \&Arulrajah, A. A. (2016): The relationships among environmental training, environmental attitude of employee and environmental orientation of organization. Proceedings of $3^{\text {rd }}$ Jaffna University International Research Conference (JUICE), University of Jaffna, 61-67.

Thevanes, N., \&Mangaleswaran, T.(2018). Relationship between work life balance and job performance of employees.IOSR Journal of Business and Management (IOSR-JBM) 20(5), 11-16.

$\mathrm{Xu}$, L. (2009). View on work-family linkage and work-family conflict model. International Journal of Business and Management, 4(2), 229-233.

Wheatley, D. (2016). Employee satisfaction and use of flexible working arrangements. Work, Employment \& Society. 31(4), 567-585.

Yuan, F., \& Woodman, R. W. (2010). Innovative behaviour in the workplace: The role of performance and image outcome expectations. Academy of Management Journal, 53(2), 323342

Zulch, G., Stock, P., \& Schmidt, D. (2012).Analysis of the strain on employees in the retail sector considering work-life balance. Work, 41(1), 2675-2682. 
Dr. Miebaka Dagogo Tamunomiebi is an Associate Professor of Organizational Behaviour and Human Resources Management in the Department of Management, Faculty of Management Sciences, Rivers State University, Port Harcourt, Nigeria.

Constance Oyibo is a Doctoral Candidate in the Department of Management, Faculty of Management Sciences, Rivers State University, Port Harcourt, Rivers State, Nigeria. 